\title{
Mollusks from Pliocene and Pleistocene seep deposits in Leyte, Philippines
}

Steffen Kiel, Yolanda M. Aguilar, and Tomoki Kase

Acta Palaeontologica Polonica 65 (3), 2020: 589-627 doi:https://doi.org/10.4202/app.00756.2020

We report 44 mollusk species from four Pliocene to Pleistocene seep deposits in Leyte Island, Philippines. The bivalves are represented by 30 species, of which eleven are new (Conchocele majimai, Conchocele visayaensis, Channelaxinus antipoloensis, Dulcina liogliogensis, Dulcina magoi, Elliptiolucina fernandoi, Lucinoma canudai, Lucinoma velosoi, Lucinoma tinagoensis, Lucinoma kosatorea, Archivesica pastori), six are extant species known from the Philippines and surrounding waters (Meganodontia acetabulum, Lucinoma dulcinea, Lucinoma aff. kastoroae, Vesicomya margotae, "Pliocardia" ticaonica, "Pliocardia" indica), and five are extant species known from Japanese waters (Bathymodiolus securiformis, Divalucina soyoae, Archivesica kawamurai, Pliocardia kuroshimana, Elliptiolucina ingens). Remarkable about those latter species is that only a single one of them occurs as fossil in Japan, despite Japan's rich fossil record of seep communities. This together with the large number of new species with close relatives in Japan suggests that at least part of the modern Japanese vent and seep fauna originated in Philippine waters. More than one third (twelve) of the bivalve species reported here belong to the family Lucinidae, which is also very species-rich in shallow waters around the Philippines. Four new gastropods are described: Margarites hayashii, Vetulonia philippinensis, Cataegis ramosi, and Provanna azurini.

Key words: Gastropoda, Bivalvia, chemosymbiosis, Neogene, Quaternary, Indo-Pacific Ocean.

Steffen Kiel [steffen.kiel@nrm.se], Swedish Museum of Natural History, Department of Palaeobiology, Box 50007, 10405 Stockholm, Sweden.

Yolanda M. Aguilar [yolanda.maac@yahoo.com], Mines and Geosciences Bureau, Marine Geological Survey Division, Quezon City, Philippines. Tomoki

Kase [neritopsis@gmail.com], National Museum of Nature and Science, Department of Geology and Paleontology, Tsukuba, Ibaraki 305-0005, Japan. 
distribution, and reproduction in any medium, provided the original author and source are credited.

For Full text $(2,480.2 \mathrm{kB})$ 